\title{
Xenobiotic metabolism and its physiological consequences in high-Antarctic Notothenioid fishes
}

\author{
Anneli Strobel ${ }^{1}\left(\mathbb{D} \cdot\right.$ Roger Lille-Langøy $^{2,5} \cdot$ Helmut Segner $^{3} \cdot$ Patricia Burkhardt-Holm $^{4} \cdot$ Anders Goksøyr $^{2}$. \\ Odd André Karlsen²
}

Received: 27 June 2021 / Revised: 7 December 2021 / Accepted: 9 December 2021 / Published online: 26 December 2021

(c) The Author(s) 2021

\begin{abstract}
The Antarctic ecosystem is progressively exposed to anthropogenic contaminants, such as polycyclic aromatic hydrocarbons (PAHs). So far, it is largely unknown if PAHs leave a mark in the physiology of high-Antarctic fish. We approached this issue via two avenues: first, we examined the functional response of the aryl hydrocarbon receptor (Ahr), which is a molecular initiating event of many toxic effects of PAHs in biota. Chionodraco hamatus and Trematomus loennbergii served as representatives for high-Antarctic Notothenioids, and Atlantic cod, Gadus morhua as non-polar reference species. We sequenced and cloned the Ahr ligand binding domain (LBD) of the Notothenioids and deployed a GAL4-based luciferase reporter gene assay expressing the Ahr LBD. Benzo[a]pyrene (BaP), beta-naphthoflavone and chrysene were used as ligands for the reporter gene assay. Second, we investigated the energetic costs of Ahr activation in isolated liver cells of the Notothenioids during acute, non-cytotoxic BaP exposure. In the reporter assay, the Ahr LBD of Atlantic cod and the Antarctic Notothenioids were activated by the ligands tested herein. In the in vitro assays with isolated liver cells of high-Antarctic Notothenioids, $\mathrm{BaP}$ exposure had no effect on overall respiration, but caused shifts in the respiration dedicated to protein synthesis. Thus, our study demonstrated that high-Antarctic fish possess a functional Ahr that can be ligand-activated in a concentration-dependent manner by environmental contaminants. This is associated with altered cost for cellular protein synthesis. Future studies have to show if the toxicant-induced activation of the Ahr pathway may lead to altered organism performance of Antarctic fish.
\end{abstract}

Keywords Notothenioids · Aryl hydrocarbon receptor $\cdot$ Polycyclic aromatic hydrocarbons $\cdot$ Luciferase reporter gene assay · Hepatocyte metabolism

Anneli Strobel

anneli.strobel@awi.de

1 Alfred Wegener Institute Helmholtz Centre for Polar and Marine Research, Am Handelshafen 12, 27570 Bremerhaven, Germany

2 Department of Biological Sciences, University of Bergen, Thormøhlensgate 53B, 5006 Bergen, Norway

3 Department of Infectious Diseases and Pathobiology, Centre for Fish and Wildlife Health, University of Bern, Länggassstrasse 122, 3012 Berne, Switzerland

4 Man-Society-Environment, University of Basel, Vesalgasse 1, 4051 Basel, Switzerland

5 Institute of Marine Research, P.O. Box 1870, Nordnes, 5817 Bergen, Norway

\section{Introduction}

The Southern Ocean is progressively exposed to anthropogenic environmental influences, amongst them contamination by lipophilic organic contaminants including the persistent organic pollutants (POPs) such as dioxin-like compounds and polycylic aromatic hydrocarbons (PAHs). These contaminants are introduced to Antarctica via atmospheric long-range transport and global distillation processes, but also by local sources such as ships or research stations (Wania and Mackay 1996; IPCC 2014). Importantly, studies showed that the lipophilic contaminants can enter the Antarctic trophic food web, in which they bioaccumulate and biomagnify (Corsolini et al. 2002, 2003). Some studies already demonstrate that Antarctic fishes accumulate anthropogenic contaminants such as PAHs or halogenated aromatic hydrocarbons (HAHs), in both low- and high-Antarctic 
regions (Goutte et al. 2013; Strobel et al. 2016, 2018). The consequences for the Antarctic fauna, however, are still largely unknown (Bennett et al. 2015). The majority of the Antarctic fish species belong to the suborder of the Notothenioidei, which are endemic to the Southern Ocean (Eastman 2005; Matschiner et al. 2011). The stable, permanently cold and oxygen-rich waters, as well as low competition in this extreme environment, promoted unique evolutionary adaptations of the Notothenioids (Garofalo et al. 2009). One of the most prominent functional losses, for example, are the genetic mutations that caused losses of haemoglobin and myoglobin expression in the so-called 'white-blooded icefishes' (Channichthyidae) (Sidell and O'Brien 2006). Together with other physiological adaptations, such as the expression of antifreeze-glycoproteins and low metabolic rates, the icefish can only survive at constant and stable environmental conditions. Icefish are thus considered to be the most sensitive amongst the Antarctic fishes to the slightest of environmental perturbation (Barnes and Peck 2008; Beers and Sidell 2011). Another example for functional losses is the translocation of the mitochondrial genes encoding NADH dehydrogenase subunit 6 (ND6) in some high-Antarctic Notothenioids, which has considerable consequences for the amino acid sequence of the ND6 (Papetti et al. 2007; Mark et al. 2012). Even though physiological studies proved this translocation as functionally neutral, this example reflects the evolutionary peculiarities of Antarctic Notothenioids and the need to link findings at the gene expression level to the actual functionality of a protein.

Overall, Antarctic fish have successfully evolved numerous adaptations to their extreme as well as stable environment, but this may impose costs with respect to their capability to respond to changes in the environment. A molecular initiating event in the toxicity of many environmental contaminants, including dioxin-like compounds and PAHs, is ligand binding to and activation of the aryl hydrocarbon receptor (Ahr) (Denison and Nagy 2003).

The Ahr is a member of the family of basic helix-loophelix (bHLH) Per-Arnt-Sim (PAS) transcription factors. The cytosolic form of this transcription factor is activated by the binding of ligands to the ligand binding domain (LBD) of the Ahr. After binding, it regulates the transcription of a number of biotransformation enzyme genes, such as cytochrome P450 1A (cypla) (King-Heiden et al. 2012). The expression or up-regulation of $a h r$ and cypla are thus frequently used as biomarkers to assess the exposure of marine and freshwater fish to Ahr-binding contaminants (e.g. Sleiderink et al. 1995; Yamauchi et al. 2006; Jönsson et al. 2010; King-Heiden et al. 2012; Strobel et al. 2018). When it comes to Antarctic fish, only a handful of studies investigated the inducibility of cypla by xenobiotics in PAH exposed Notothenioids such as Trematomus bernacchii and Chionodraco hamatus (Focardi et al. 1995; Miller et al. 1998; Regoli et al. 2005). Just a single study focussed on the quantitative expression of $a h r$ in contaminant-exposed Antarctic eelpout Pachycara brachycephalum, a non-Notothenioid fish species belonging to the deep-sea zoarcids (Strobel et al. 2018). However, the Ahr of the Notothenioids, which are highly endemic to the Southern Ocean, has not been characterized so far, especially not for its actual functionality.

Bearing in mind the evolutionary, functional losses and transactivation of genes found in Antarctic fishes, there is a need for demonstrating $a h r$ gene expression to actually assess the capacity of xenobiotics to functionally activate the Ahr signalling pathway. As benchmark for the evolution of functional activation of Ahr signalling in Notothenioids, a comparison should be performed to Ahr activation in fish species from non-Antarctic regions. To assess the question of Ahr functionality in Antarctic Notothenioids, we used the well-established tool of reporter gene assays in the present study. These assays can reflect the binding to and activation of fish Ahr by xenobiotics in vitro. Importantly, it provides the possibility to qualitatively compare the capacities of the Ahr system between species (Billiard et al. 2002; Evans et al. 2005; Doering et al. 2015).

Beyond the evaluation of the molecular functionality of the Ahr pathway in Antarctic Notothenioids, the question remains which physiological and toxicological consequences could arise from this. The liver is a central organ in the Ahr-mediated metabolism of xenobiotics (Hinton et al. 2008), and thus, activation of the Ahr pathway is likely to be accompanied by metabolic costs. Some studies already report on an additional fraction of energy that is needed for detoxification processes, and is related to xenobiotics bioaccumulation (Ng and Gray 2011; Manciocco et al. 2014). Particulary for Antarctic fish, with their delicate energy resources and physiological specialization to the permanent cold (Pörtner 2006), such costs may be critical.

The present study aimed to test if organic pollutants leave a mark in the physiology of Antarctic fish, focussing at the molecular and cellular level. We hypothesize that Antarctic Notothenioids show functional losses of the cellular defensome-here, the Ahr, as it is the case with other elements of the defensome in Antarctic fish, e.g. the heat shock response, or the xenosensing pregnane $\mathrm{X}$ receptor (Pxr) in several fish species (Eide et al. 2018, 2021). To test this hypothesis, we analysed the presence of $a h r$ transcripts of two high-Antarctic Notothenioids, sequenced the LBD and assessed by means of a GAL4-based luciferase reporter gene assay if the LBD of Ahr can be transactivated by BaP, a model PAH. We compared the $\mathrm{BaP}$ response with two additional compounds, chrysene and beta-naphthoflavone (BNF), and used Atlantic cod, Gadus morhua, as reference species. In order to gain insight into the metabolic costs of potential Ahr activation, we then performed respirometric measurements in isolated liver cells of the high-Antarctic fish, which were incubated 
under control conditions or under exposure to non-cytotoxic concentrations of $\mathrm{BaP}$.

The two Antarctic species selected for this study were the red-blooded T. loennbergii and the white-blooded C. hamatus. Both species are benthic and they are widely distributed around the Antarctic continent between $\sim 65$ and $\sim 76^{\circ} \mathrm{S}$. Due to this distribution, they are classified as 'high-Antarctic' species (Gon and Heemstra 1990; Eastman 2005).

\section{Materials and methods}

\section{Fish samples}

Individuals of the high-Antarctic Notothenioids, C. hamatus and $T$. loennbergii, were caught by means of bottom trawls between 6th December 2015 and 14th February 2016 during cruise PS96 of the German research vessel $R V$ Polarstern at $75^{\circ} \mathrm{S}, 30-38^{\circ} \mathrm{W}$. T. loennbergii was caught at $750 \mathrm{~m}$ depths, $C$. hamatus at $300 \mathrm{~m}$ depths. Only fish which were in a good condition were taken from the trawls or the aquarium facilities on board and anaesthetized in $0.5 \mathrm{~g} * \mathrm{~L}^{-1} 1$ tricaine methano-sulphonate (MS-222) before sampling.

Fish liver was either sampled for consecutive cell extraction, or snap-frozen in liquid nitrogen and stored at $-80{ }^{\circ} \mathrm{C}$ for further analysis.

\section{Test compounds as Aryl hydrocarbon receptor 2 agonists}

The following compounds were used as $\mathrm{Ahr} 2$ agonists in the present study: BaP, beta-naphthoflavone (BNF) and chrysene. All compounds were dissolved in dimethyl sulfoxide (DMSO 0.01\%) supplied by Sigma Aldrich.

\section{RNA preparation, CDNA synthesis, PCR and cloning of high-Antarctic fish Aryl hydrocarbon receptor}

Total RNA was extracted from frozen liver tissue using a phenol-chloroform extraction. About $25-40 \mathrm{mg}$ of frozen liver tissue was homogenized in $1 \mathrm{ml}$ TriReagent ${ }^{\circledR}$ (Sigma-Aldrich, Buchs, Switzerland) in a TissueLyser (FastPrep-24 ${ }^{\mathrm{TM}}$, MP Biomedicals, Lucerna Chem AG, Switzerland) twice with a duration of $45 \mathrm{~s}$. The homogenization steps were performed under constant cooling with dry ice. After the phenol-chloroform extraction, the RNA was washed two times with ice-cold $75 \%$ ethanol. Afterwards, DNA was removed from the RNA samples using the DNA-free ${ }^{\mathrm{TM}}$ DNA Removal Kit (Ambion, life technologies, Thermo Fisher Scientific Inc.). RNA quality and integrity was verified by capillary electrophoresis (Bioanalyzer, Agilent Technologies, CA, USA). Only RNA samples of the best quality (RIN >9.8) were used for the subsequent experiments.

For synthesis of double-stranded complementary DNA (cDNA), $0.5 \mu \mathrm{g}$ of DNA-free RNA was reverse transcribed using the High Capacity cDNA Reverse Transcription Kit by Applied Biosystems (USA). The cDNA samples were purified with the DNA Clean \& Concentrator ${ }^{\mathrm{TM}_{-}} 5$ kit, and the samples were stored at $-20{ }^{\circ} \mathrm{C}$ until analysed.

$A h r$ gene sequences are not available for $C$. hamatus or T. loennbergii in GenBank. Therefore, we designed primers located in conserved regions of piscine Ahr (bHLH and PAS-B), based on published sequence information in Karchner et al. (2005) and additionally on a putative Ahr sequence of the Antarctic fish Notothenia coriiceps (GeneBank accession no. \#NW_011336470.1 and \#XM_010778753; accession numbers are abbreviated with \# from now on) (Table S1, supplementary). Using cDNA as a template, we amplified PCR fragments of the expected size ( $900 \mathrm{bp})$, which were cloned (TOPO TA, Invitrogen Corporation, Carlsbad, California, USA) and sequenced (Microsynth AG, Balgach, Switzerland) afterwards.

\section{5'-3' rapid amplification of CDNA ends (RACE) PCR}

5'-3' RACE (FirstChoice® RLM-RACE Kit, Ambion Inc., USA) was performed according to the manufacturer's protocol to obtain the full sequence of the Ahr. The genespecific primers (GSPs) used for 5'-3' RACE are given in Table $\mathrm{S} 1$. The PCR products were analysed on a $0.8 \%$ agarose gel, and positive products of $\sim 800-900$ bp length were extracted using the Zymoclean ${ }^{\mathrm{TM}}$ Gel DNA Recovery Kit (Zymo Research, California, USA). The purified PCR products were then cloned into $\mathrm{pCR} 4-\mathrm{Topo}{ }^{\circledR}$ vectors (Invitrogen, Thermo Fisher Scientific Inc.). At least six plasmids per PCR product were purified with Plasmid Miniprep Kit by Zymo Research (Zymo Research Corporation, USA) and subsequently sequenced by Microsynth AG (Switzerland). The obtained sequences were verified by BlastN (ncbi. nlm.nih.gov) and analysed and assembled with CLC Main Workbench software (Qiagen, Denmark). The assembled sequences of the 5'-3' RACE yielded a 1960 bp fragment for $C$. hamatus and a $3300 \mathrm{bp}$ fragment for T. loennbergii, covering the bHLH, PAS-A and LBD including PAS-B. Further attempts to obtain the full-length Ahr sequences were not successful. Alignments were performed using CLC Main Workbench software (Qiagen, Denmark). The aligned amino acid sequences from seabream (Sparus aurata) Ahr1 \#ABY82367, seabream Ahr2 \#AAN05089, killifish (Fundulus heteroclitus) Ahr1 \#O57452, killifish Ahr2 \#AAC59696, goldfish (Carassius auratus) Ahr1 \#ACT79400, goldfish Ahr2 \#ACT79401, zebrafish (Danio rerio) Ahr1 \#NP571103, zebrafish Ahr2 \#NP571339, dogfish (Mustelus canis) Ahr1 \#AAC60335, dogfish Ahr2 AAC60336, red 
seabream (Pagrus major) Ahr1 \#BAE02821, red seabream \#BAE02825, C. hamatus Ahr and T. loennbergii Ahr were used to construct a maximum likelihood phylogenetic tree using the neighbour-joining method (in CLC Main Workbench, Qiagen, Aarhus, Denmark).

The subsequent luciferase reporter gene assay was conducted with clones of the LBD from $C$. hamatus and $T$. loennbergii, corresponding to AA238-414 in zebrafish Ahr2; UniProt: \#Q9YGV3). A genome analysis of the Notothenioids investigated herein was not covered within the framework of this study.

\section{Luciferase reporter gene assay}

In vitro Ahr reporter gene assays, such as the luciferase reporter gene assay, are common methods for the semiquantitative activation of PAHs and dioxin-like compounds in fish and have been used in several species from various environmental temperature regimes, and a feasible choice in case the full-length Ahr receptor is not available (Roy et al. 2011; Chao et al. 2012; Doering et al. 2015). In the present study, the luciferase reporter gene assays were performed essentially as described in (Grun et al. 2002; Lille-Langoy et al. 2015), however, transfection was performed with the TransIT-LT1 reagent (Mirus BIO, USA) as described by the supplier. In brief, we created plasmids encoding fusion proteins of the high-Antarctic Notothenioid Ahr2 LBD region (corresponding to AA238-414 in zebrafish Ahr2, UniProt: \#Q9YGV3) and of yeast Gal4-DNA-binding domain (DBD). The plasmid encoding a fusion protein encoding the GAL4DNA-binding domain and the LBD of the Atlantic cod AHR (AA221-439) was already available to us (Madsen 2016).

The plasmid containing the Ahr2-GAL4 fusion protein was co-transfected into COS7 cells together with a reporter plasmid (MH100)x4tk luc and a CMV-promoter based plasmid constitutively expressing B-galactosidase as a transfection control (Forman et al. 1995; Blumberg et al. 1998). The COS7 cells were maintained in phenol red Dulbecco's modified Eagle medium (DMEM), supplemented with $10 \%$ foetal bovine serum (FBS), $4 \mathrm{mM} \mathrm{L}$-glutamate, $1 \mathrm{mM}$ sodium pyruvate at $37^{\circ} \mathrm{C}$ with $5 \%$ carbon dioxide $\left(\mathrm{CO}_{2}\right)$. Penicillin and streptomycin at concentrations of $100 \mathrm{U}^{*} \mathrm{~mL}^{-1}$ were added to prevent microbial contamination in the growth media. Cells were seeded in 96-well plates at densities of $5^{*} 10^{3}$ cells per well and cultivated for $24 \mathrm{~h}$. Cells were then transfected with the luciferase reporter, the $\beta$-galactosidase control plasmids and plasmids encoding high-Antarctic Notothenioid Ahr2 LBD-GAL4-DBD fusion proteins. After $24 \mathrm{~h}$ of incubation, cells were exposed to the test compounds dissolved in DMSO at seven different final concentrations in phenol red-free DMEM supplemented with $10 \%$ heatinactivated, charcoal-resin stripped FBS. The concentrations of $\mathrm{BaP}$ ranged from 0.0013 to $20 \mu \mathrm{M}$, of $\mathrm{BNF}$ from 0.0003 to $4 \mu \mathrm{M}$ and of chrysene from 0.0032 to $50 \mu \mathrm{M}$, based on preliminary studies with Atlantic cod elaborating suitable compound concentration ranges and exposure durations (Aranguren-Abadía et al. 2020). Twenty-four hours postexposure, the COS7 cells were lysed and enzyme activities of luciferase and $\beta$-galactosidase measured as luminescence and absorbance, respectively (EnSpire multimode plate reader, Perkin Elmer, USA). Each compound was measured in triplicate wells and five different assays. The activities of B-galactosidase resulting from the constitutive expression of the control plasmid were monitored and used to correct for differences in transfection efficiency between the wells.

Prior to the start of the luciferase reporter gene assay with our Ahr-fusion proteins, viability assays were performed to make sure that non-toxic concentrations of the individual test compounds were used. This cytotoxicity assay basically followed the experimental procedure of the luciferase reporter gene assay, without transfection of the reporter-, effector- and control plasmids. In the end, cell viability was measured with 5-carboxyfluorescein diacetate, acetoxymethyl ester (CFDA-AM) to test for membrane integrity, and with resazurin to measure cell metabolism, as fluorescence in a EnSpire multimode plate reader (Perkin Elmer, USA) as previously described (Blanco et al. 2018).

The activation of Ahr in cells exposed to the toxicants was expressed as transfection efficiency corrected luciferase activities (normalized relative luciferase units) relative to activities in solvent control cells (fold-induction), thereby accounting for any (unlikely) Ahr background activities in the assay as such. Dose-response curves were fitted by linear regression analysis in Prism 5.02 (GraphPad Software, Inc., La Jolla, USA). The statistical difference of the cells exposed to compounds compared to control (DMSO) was evaluated by ANOVA followed by a post hoc test (Dunnett) (Software: GraphPad Prism). The statistical difference between the high-Antarctic Notothenioid Ahr LBD and Atlantic cod Ahr LBD was calculated by ANOVA. A $p \leq 0.05$ was considered to be significant. Data are presented as means \pm standard error of the mean $( \pm$ sem) .

\section{Isolation of hepatocytes}

Cells from about $2 \mathrm{~g}$ liver tissue were isolated following a protocol modified after (Mommsen et al. 1994; Segner 1998) and a protocol for the isolation of hepatocytes from G. morhua after Stapp et al. (2015). All isolation buffers and media were chilled on ice prior to use. The liver was excised and immediately placed in Hanks medium containing $30 \mathrm{mM} \mathrm{NaCl}$ and $10 \mathrm{mM}$ 4-(2-hydroxyethyl)-1-piperazineethanesulfonic acid (HEPES). The liver was then flushed with Hanks medium substituted with $30 \mathrm{mM} \mathrm{NaCl}$, $10 \mathrm{mM}$ HEPES and $5 \mathrm{mM}$ Ethylenediamine Tetraacetic Acid (EDTA). Afterwards, it was perfused and digested 
for $1-1.5 \mathrm{~h}$ with Hanks medium containing $30 \mathrm{mM} \mathrm{NaCl}$, $10 \mathrm{mM}$ HEPES, $1 \% w^{*} v^{-1} \mathrm{BSA}$ and $1500 \mathrm{U}^{*} \mathrm{ml}^{-1}$ collagenase type $1 \mathrm{~A}$. After digestion time, the digestion process was stopped by adding $10 \%\left(v^{*} v^{-1}\right)$ fetal calf serum (FCS). Subsequently, hepatocytes were filtered through a series of nylon mesh $(250 \mu \mathrm{m}, 105 \mu \mathrm{m}$ and $50 \mu \mathrm{M})$ followed by centrifugation at $100 \mathrm{~g}, 0{ }^{\circ} \mathrm{C}$, for $3 \mathrm{~min}$. The concentrated hepatocytes were washed three times in Hanks substituted with $2 \mathrm{mM} \mathrm{CaCl} 2$ and resuspended in Leibovitz L15 (+ glutamine, Sigma L4386) containing $15 \mathrm{mM} \mathrm{NaCl}$ and $10 \mathrm{mM}$ HEPES. Cells were stored on ice on a shaking desk for at least one hour prior to experimentation. Cell numbers were assessed in a Fuchs-Rosenthal haemocytometer dish and cell viability was determined by Trypan blue exclusion.

In preliminary experiments, we observed increased mortality of the cells six hours after isolation. We thus chose the maximum duration of the subsequent assays accordingly.

\section{Measurement of oxygen consumption}

Cell-respiration was measured in vitro in airtight $0.5-\mathrm{ml}$ glass respiration chambers containing magnetic stirrers from Loligo Systems (Viborg, Denmark). Oxygen concentrations within the chambers were detected once per minute with fibre-optic oxygen sensors (Polymer Optical Fiber PSt3 \& Oxygen Sensor Spots, PreSens-Precision Sensing GmbH, Germany) connected to an OXY-4 multi-channel Oxygen Meter (PreSens, Germany). Before each measurement, the oxygen probes were calibrated at 100 and $0 \%$ oxygen concentration within the respiration chambers containing the respiration medium chilled at $0.5{ }^{\circ} \mathrm{C}$. The respiration chambers were temperature controlled at $0.5^{\circ} \mathrm{C}$ by a water bath, three chambers were measured in parallel.

Cell solutions were diluted to achieve final cell counts of 2.5 million cells per chamber. Cells were incubated in the temperature-controlled glass respiration chambers for one hour prior to measurement at the respective measurement conditions to ensure that $\mathrm{BaP}$ was metabolized by the cells.

In vitro studies on non-polar fish demonstrated intrinsic clearance of $\mathrm{BaP}$ in isolated hepatocytes or liver microsomal fractions already at concentrations of $5 \mu \mathrm{M} \mathrm{BaP}$ and below (Fay et al. 2014; Möller et al. 2014b). To avoid potential cytotoxicity effects by $\mathrm{BaP}$ in our experiments, but to make sure $\mathrm{BaP}$ metabolism was induced in the isolated hepatocytes, we exposed isolated hepatocytes to $0.5,1,5,10$ and $20 \mu \mathrm{M} \mathrm{BaP}$ for a period of $24 \mathrm{~h}$ in preliminary experiments with three samples of $T$. loennbergii and $C$. hamatus each. Cytotoxicity and viability were analysed with Trypan blue exclusion and a Neutral red assay (Sigma) (Weyermann et al. 2005). The increasing BaP concentrations revealed no significant differences in cell viability, mortality or any significant cytotoxicity effects (data not shown), and $10 \mu \mathrm{M} \mathrm{BaP}$ was selected as concentration for the acute $\mathrm{BaP}$ exposure assays.
Oxygen consumption was recorded in control cells, cells + DMSO (solvent control) and cells $+10 \mu \mathrm{M}$ BaP. Cycloheximide was used to measure energy allocation to protein biosynthesis. The cycloheximide concentration was applied to inhibit protein biosynthesis at the lowest effective dose $(100 \mu \mathrm{M})$ according to Stapp et al. (Stapp et al. 2015). Fourty-five minutes after start of measuring the cellular respiration, the inhibitor was added.

The test compounds and inhibitor were dissolved in DMSO; added volumes did not exceed $1 \%$ of the final assay volume to avoid cytotoxicity. All chemicals were purchased from Sigma Aldrich, Switzerland.

Oxygen consumption rates were calculated using the slope of oxygen depletion within the chambers. Hepatocyte respiration is displayed as $\mathrm{MO}_{2}$ in pmol $\mathrm{O}_{2} \mathrm{~min}^{-1} 10^{6}$ cells $^{-1}$.

The hepatocyte respiration data were analysed using Prism 5.02 (GraphPad software, Inc., La Jolla, CA, USA). All data were tested for normality (Kolmogorov-Smirnov) and homogeneity of variance. Using analysis of variance (ANOVA) followed by Tukey post-tests or pairwise comparison with two-tailed $t$-tests (Students), we evaluated statistical differences between control and BaP-exposed cells and species differences. The following parameters were analysed for statistical differences: hepatocyte respiration $\left(\mathrm{MO}_{2}\right.$ in pmol $\mathrm{O}_{2} \min ^{-1} 10^{6}$ cells $^{-1}$ ), protein biosynthesis (as \% of control respiration $\left(0^{\circ} \mathrm{C}\right.$, no BaP $)$ ) and $\mathrm{BaP}$ metabolism (as $\%$ of control respiration). A $p \leq 0.05$ was considered as significant differences. All data are presented as means \pm standard error of the mean $( \pm$ sem).

\section{Results}

\section{Sequencing and cloning of high-Antarctic fish Ahr}

Using primers located in conserved regions (bHLH and PAS-B) of teleost fish Ahr, we were able to amplify and clone cDNA fragments of the predicted size $(\sim 900 \mathrm{bp})$ of both $C$. hamatus and T. loennbergii. The nucleotide sequences of these cloned PCR products were highly similar to sequences of the Ahr of other teleost fish species (BlastN at ncbi.nml.nig.gov; Figure S1 and S2, supplementary). For both high-Antarctic species, only a single Ahr sequence was obtained in several cloning approaches. The obtained cDNA and deduced amino acid sequences covered the LBD and PAS-B domain (Genbank accession numbers: T. loennbergii: \#MG825103, C. hamatus: \#MG825104; Fig. 1).

The two amino acid sequences reported here for the two high-Antarctic fish species display 95\% sequence identity to each other. An alignment with other fish Ahrs revealed conserved regions and similarities in the LBD amino acid sequences. Amongst others, the Ahr LBD of C. hamatus and 


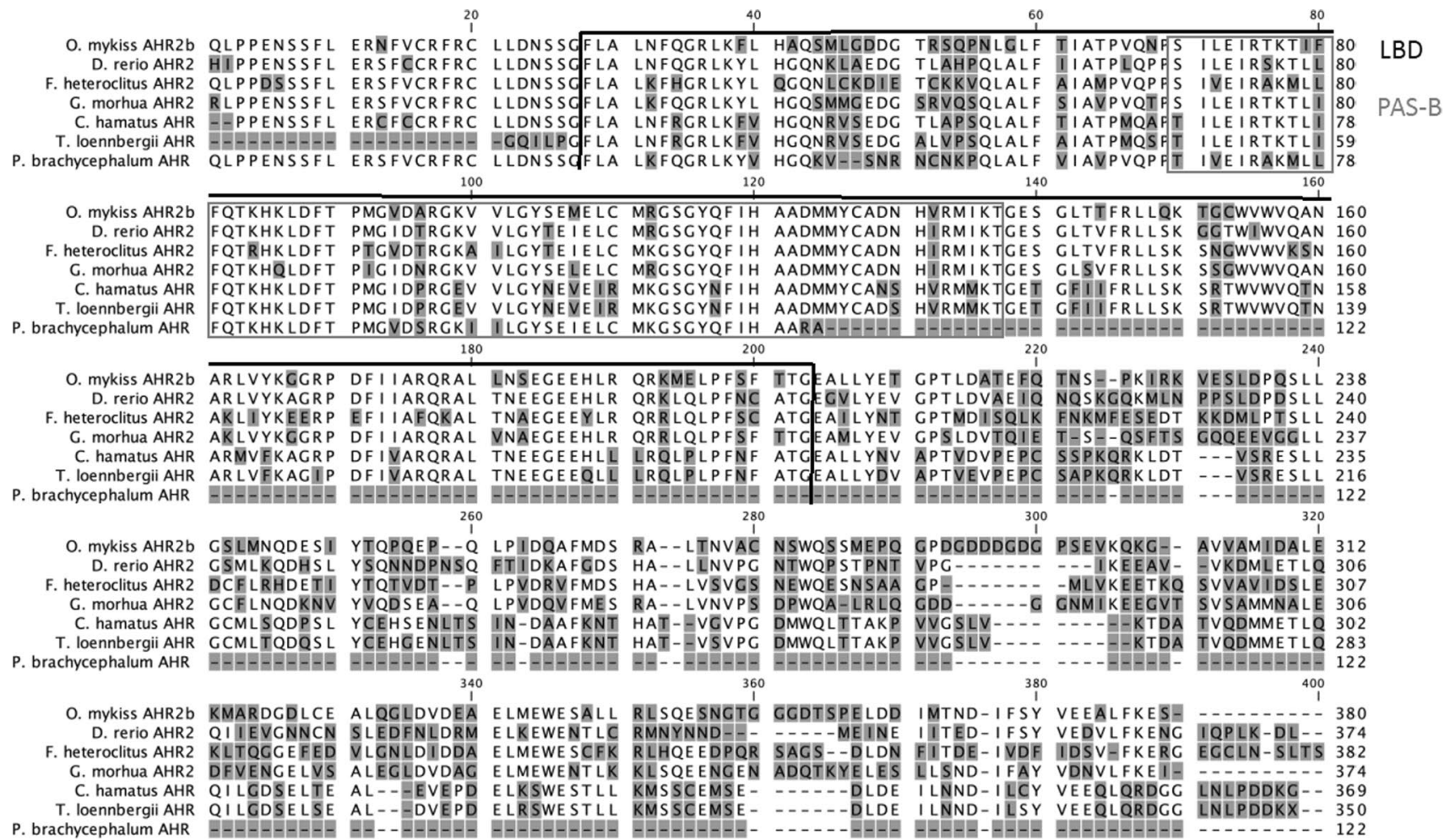

Fig. 1 Alignment of the ligand binding domain (LBD) and PAS-B amino acid sequences of rainbow trout, zebrafish, killifish, Atlantic cod and high-Antarctic Notothenioid Ahrs. The amino acid sequences were aligned using CLC Main Workbench. Differences in amino acid sequences are shaded in grey. The LBD is highlighted by black brackets, the PAS-B domain is depicted by a grey box. GenBank accession numbers are: rainbow trout (Oncorhynchus mykiss) $\mathrm{Ahr} \beta$ \#NP001117724.1, zebrafish (Danio rerio) Ahr2 \#NP571339.1, killifish (Fundulus heteroclitus) Ahr2 \#AAC59696.3, Gadus morhua Ahr2, Chionodraco hamatus Ahr, Trematomus loennbergii Ahr, Antarctic eelpout (Pachycara brachycephalum) Ahr $\beta$ \#KY747527.1

to solvent (DMSO)-treated cells. For comparison, we also assessed the activation of the Ahr2 LBD from G. morhua. A cytotoxicity test ensured that the cells were not exposed to cytotoxic (i.e. lethal) concentrations of the test compounds (Table S2, supplementary).

The results of the in vitro ligand activation of the Ahr LBD are summarized in Table S3 (supplementary) and Fig. 3, where the relative increase in luciferase activity is displayed for the five highest concentrations of each compound. All three compounds tested in the GAL4-LBD based luciferase reporter gene assay caused a concentration-dependent induction in luciferase activity in the high-Antarctic fish and in Atlantic cod. Beta-naphthoflavone caused the strongest induction of luciferase activity, which was significantly higher than in the DMSO-treated cells at all concentrations above $0.032 \mu \mathrm{M}$ (Table S3, supplementary and Fig. 3). BaP significantly increased luciferase activity compared to the DMSO-exposed cells only at the concentration of $20 \mu \mathrm{M}$ in all three species, and higher concentrations were not tested.

The luciferase activity rose with increasing chrysene concentration and displayed the highest, significantly increased luciferase activity at $10 \mu \mathrm{M}$ in all three species (for detailed 


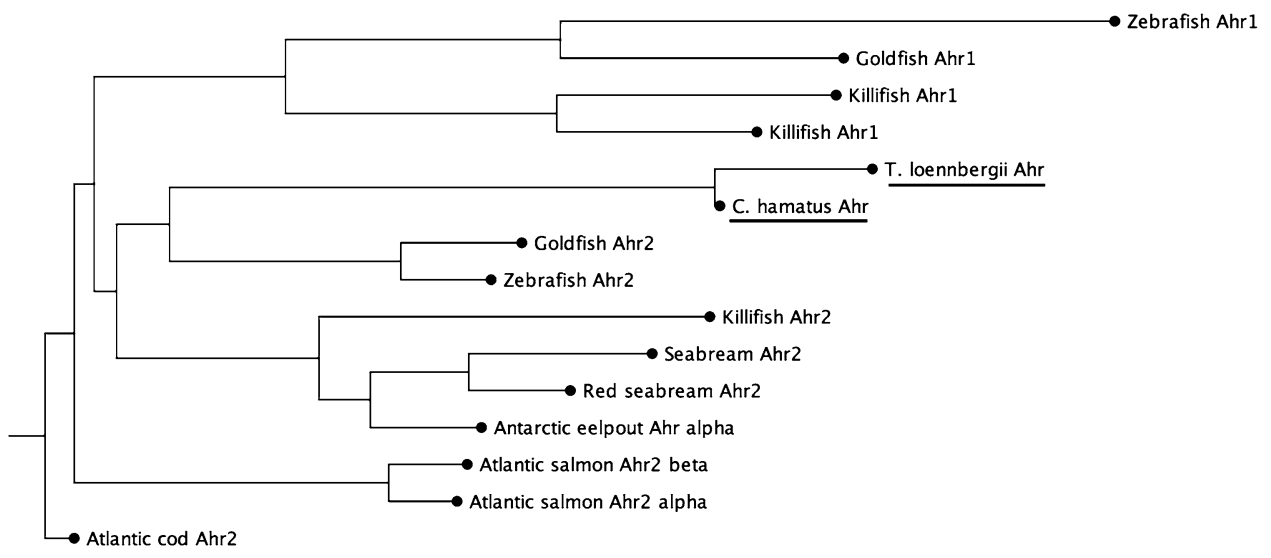

0.250

Fig. 2 Phylogenetic analysis of fish Ahr amino acid sequences. The amino acid sequences were aligned using CLC Main Workbench. The phylogenetic tree was constructed by the neighbour-joining method using CLC Main Workbench, with the branch lengths corresponding to the evolutionary distance between sequence clusters. The GenBank accession of the sequences are as follows: seabream Ahr2 \#AAN05089, killifish (Fundulus heteroclitus) Ahr1 \#O57452, killifish (Fundulus heteroclitus) Ahr2 \#AAC59696, goldfish (Carassius

statistics, see Table S3, supplementary). At $50 \mu \mathrm{M}$, the luciferase activity decreased already, indicating a slight inhibitory effect at such high concentrations, although no significant cytotoxicity was observed (Table S2, supplementary). A species comparison between the three fish revealed that the luciferase activity produced by transactivation of the Ahr LBD of $C$. hamatus was significantly higher than in $T$. loennbergii at 10 and $50 \mu \mathrm{M}$ chrysene, but not different to $G$. morhua with this assay (for detailed statistics, see Table S3, supplementary).

\section{Effect of benzo[a]pyrene on the hepatocyte respiration and costs for benzo[a]pyrene metabolism}

In preliminary experiments, we could show that DMSO (the inhibitors' solvent), had no significant effect on the hepatocyte respiration rates, compared to the control hepatocytes.

Figure 4 displays the hepatocyte respiration rate in $T$. loennbergii and $C$. hamatus at $0{ }^{\circ} \mathrm{C}$ in control and $\mathrm{BaP}$ exposed cells. We neither measured a significant difference in hepatocyte respiration rate in control vs. BaP-exposed cells, nor between the red- and white-blooded species. In $T$. loennbergii, we measured a hepatocyte respiration rate of $0.22 \pm 0.04 \mathrm{nmol} \mathrm{O}{ }_{2} * 10^{6}$ cells $^{-1} \mathrm{~min}^{-1}(n=8)$ in the control cells, and $0.23 \pm 0.02 \mathrm{nmol} \mathrm{O}_{2} * 10^{6}$ cells $^{-1} \mathrm{~min}^{-1}(n=8)$ in the BaP-assay. In the control and BaP-exposed cells of C. hamatus, we measured a hepatocyte respiration of auratus) Ahr1 \#ACT79400, goldfish Ahr2 \#ACT79401, zebrafish (Danio rerio) Ahr1 \#NP571103, zebrafish (Danio rerio) Ahr2 \#NP571339, red seabream (Pagrus major) Ahr2 \#BAE02825, Atlantic salmon (Salmo salar) Ahr1 \#NP_001117158.1 Atlantic salmon (Salmo salar) Ahr2 $\alpha$ \#NP_001117156, Antarctic eelpout (Pachycara brachycephalum) Ahr2 $\alpha$ \#KY747528, Atlantic cod (Gadus morhua), Chionodraco (Chionodraco hamatus) Ahr2 and Trematomus (Trematomus loennbergii) Ahr2

$0.21 \pm 0.01$ and $0.25 \pm 0.04 \mathrm{nmol} \mathrm{O}{ }_{2} * 10^{6}$ cells $^{-1} \mathrm{~min}^{-1}$ $(n=6)$, respectively.

\section{Protein metabolism in benzo[a]pyrene exposed hepatocytes}

Figure 5 depicts the metabolic costs dedicated to protein biosynthesis as \% of control respiration in isolated hepatocytes of $T$. loennbergii and C. hamatus, which was $22 \%$ in the control hepatocytes of both species.

In $T$. loennbergii, the fractional oxygen demand for protein biosynthesis accounted for $22 \pm 5 \%(n=8)$ in the control hepatocytes and for $13 \pm 4 \%(n=8)$ in the BaP-exposed cells.

In the control assay of $C$. hamatus, $22 \pm 4 \%(n=6)$ of the total hepatocyte respiration was dedicated to protein synthesis. This fraction rose significantly (Unpaired $t$-test, $\left.t_{4}=2.163, p=0.048\right)$ to $40 \pm 7 \%(n=6)$ in the BaP-exposed hepatocytes.

\section{Discussion}

\section{Aryl hydrocarbon receptor sequencing and expression in high-Antarctic fish species}

In this paper, we identified and cloned a partial gene sequence of the Ahr corresponding to the Ahr LBD in the high-Antarctic Notothenioids $C$. hamatus and T. loennbergii and demonstrated that the Notothenioid Ahr LBDs are 
Fig. 3 Ligand activation doseresponse curves of Atlantic cod (Gadus morhua) ( $n=3$ ) Ahr2 ligand binding domain (Gm Ahr2), Chionodraco hamatus $(n=3)$ Ahr ligand binding domain (Ch Ahr LBD) and Trematomus Loennbergii $(n=3)$ Ahr ligand binding domain ( $\mathrm{Tl}$ Ahr LBD). The ligand activation of Ahr by selected test compounds ( $\mathbf{a}=$ beta-naphthoflavone (BNF), $b=$ Benzo[a] pyrene (BaP), $\mathrm{c}=$ chrysene) is reported as fold-increase in luciferase activity in cells exposed to the test compound over cells exposed to solvent (dimethyl sulfoxide, not shown). Each data point represents the mean of triplicate wells measured in five independent experiments $( \pm$ sem $)$. The dose-response curves were fitted by non-linear regression (GraphPad Prism). * displays a statistically significant difference in luciferase activities in compound-exposed compared to dimethyl sulfoxide -treated cells (ANOVA, $p \leq 0.05$. Detailed statistics are given in Table S3, supplementary). \# shows a significant difference in luciferase activities compared to the luciferase activity of Chionodraco hamatus (ANOVA, $p \leq 0.05$.

Detailed statistics are given in

Table S3, supplementary)
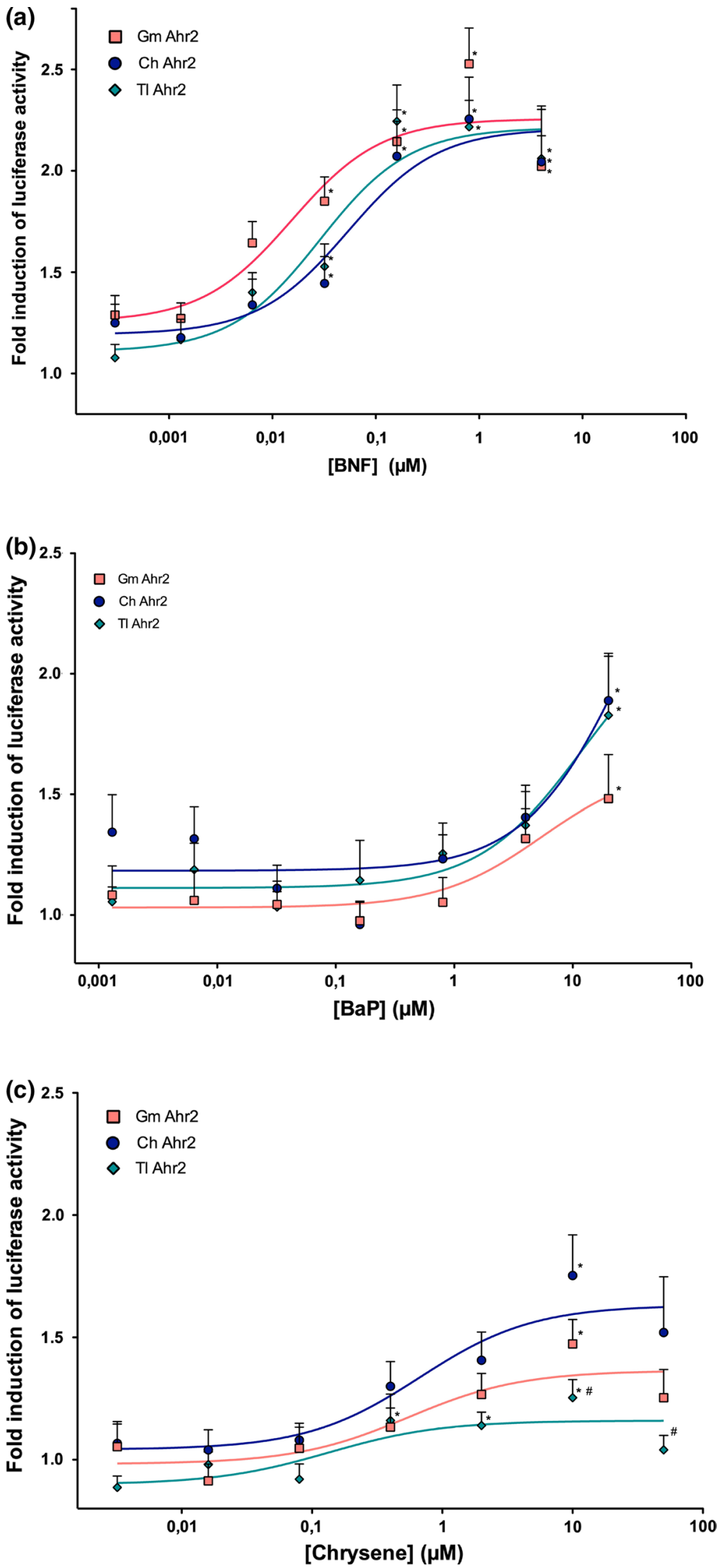


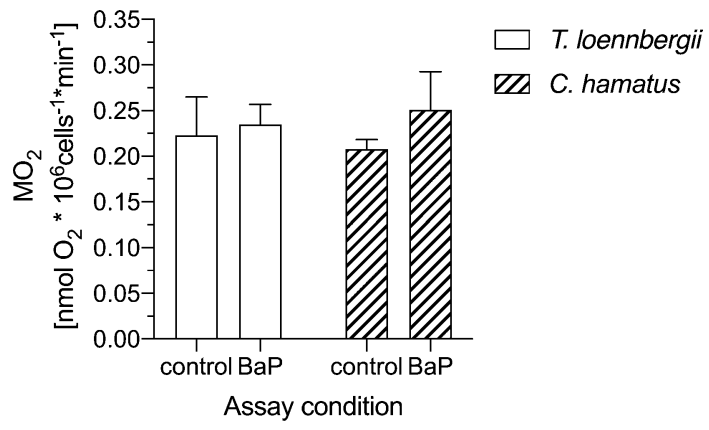

Fig. 4 Oxygen consumption $\left(\mathrm{MO}_{2}\right)$ of liver cells of Trematomus loennbergii ( $n=8$, plain bars) and Chionodraco hamatus $(n=6$, striped bars). Hepatocyte $\mathrm{MO}_{2}$ was measured under control and BaPexposed conditions at $0{ }^{\circ} \mathrm{C}$. Values are displayed as means \pm sem

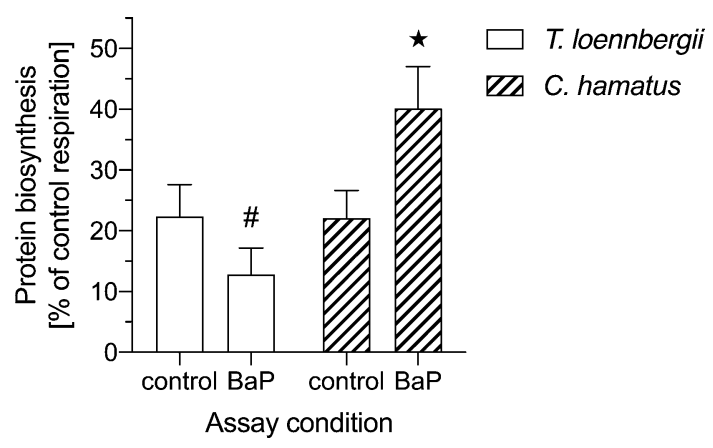

Fig. 5 Energy expenditure for protein biosynthesis in control (sham) and BaP-exposed liver cells of Trematomus loennbergii $(n=8$, plain bars) and Chionodraco hamatus ( $n=6$, striped bars) assayed at $0{ }^{\circ} \mathrm{C}$. Protein biosynthesis is displayed as \% of control (sham) respiration. The \# depicts a significant difference (unpaired $t$-test, $t_{6}=3.536$, $p=0.012$ ) to Chionodraco hamatus at the respective assay conditions. The asterisk displays a significant difference (unpaired $t$-test, $\left.t_{4}=2.163, p=0.048\right)$ ) to the protein biosynthesis in BaP-exposed liver cells of Trematomus loennbergii. Values are means \pm sem

activated by PAHs in the GAL4-based reporter gene assay. Furthermore, we demonstrated that PAHs leave a metabolic mark in hepatocytes from the two Antarctic fish species.

Fish, in contrast to mammals, do not have a single Ahr but show a high diversity of $a h r$ genes. Teleost fish possess two Ahr clades (Ahr1 and Ahr2), which can comprise several isoforms (Hahn et al. 2006). A sequence comparison of the $C$. hamatus and T. loennbergii Ahr LBD amino acid sequence with other piscine Ahrs revealed high identities with e.g. F. heteroclitus $\mathrm{Ahr} 2 \mathrm{~b}$ and other fish Ahr-like sequences. This similarity was further supported by a phylogenetic analysis, which showed that the Ahrs of C. hamatus and T. loennbergii cluster together with the Ahr2 clade of teleost fish. Furthermore, the Ahr LBD regions that we cloned from liver cDNA contained highly conserved regions when compared to other fish Ahr LBDs (Fig. 1), demonstrating that high-Antarctic Notothenioids express $a h r 2$ in the liver. Indeed, previous studies report that $a h r 2$ is expressed at particularly high levels in liver tissues of fish, and in some species also at much higher levels than ahrl (Abnet et al. 1999; Hansson and Hahn 2008; Aranguren-Abadía et al. 2020). This may explain why we could not obtain other $a h r$ isoforms in $C$. hamatus or T. loennbergii, despite several cloning attempts. Nonetheless, we cannot exclude that $a h r l$ is expressed in high-Antarctic Notothenioids as well. To our knowledge, to date only one study measured the expression of $a h r$ in an Antarctic fish species, the Antarctic eelpout (Strobel et al. 2018), and no functional information of the Ahr exists for any Antarctic teleost species. Importantly, the expression of the Ahr LBD in species like Antarctic eelpout or its presence in the investigated high-Antarctic fish does not reflect its capacity for ligand activation by Ahr agonists.

\section{Activation of high-Antarctic fish Aryl hydrocarbon receptor by polycyclic aromatic hydrocarbons}

Our results of the luciferase reporter gene assays revealed that the Ahr LBD of both high-Antarctic species and Atlantic cod responded to the exposure to $\mathrm{BaP}, \mathrm{BNF}$ and chrysene by an increase in luciferase activity and in a dose-dependent manner. Despite the differences in the protein primary sequence and potential conformation differences of the Ahr LBD of high-Antarctic fish (95\% sequence identity between the two species) and Atlantic cod (52 substitutions out of 177 amino acids), we did not observe significant differences in the activation characteristics of the Ahr LBD between the high-Antarctic fish and Atlantic cod in the assays using $\mathrm{BaP}$ and BNF as ligands. Thereby, the results of the luciferase reporter gene assay suggest that $\mathrm{Ahr}$ is an active, ligand-activated transcription factor in high-Antarctic Notothenioids. Even though the differential ligand binding affinities appear to depend on the ligand binding cavity in fish of the piscine Ahr (Fraccalvieri et al. 2013), the GAL4-based luciferase assay with the Atlantic cod Ahr LBD is less sensitive in comparison to a full-length Ahr and Arnt/XRE-based luciferase assay. Notably, the efficacy and sensitivity of Ahr towards $\mathrm{BaP}$ were shown to be considerably higher in the full-length assay, which is also in accordance with prior research on fishes (Aranguren-Abadía et al. 2020). Thus, using the fulllength $\mathrm{Ahr}$ sequences in a similar assay could potentially reveal masked differences in sensitivities amongst the highAntarctic fish and Atlantic species. Moreover, the determinants responsible for causing differences in Ahr sensitivities amongst fish species are currently not elucidated (Doering et al. 2013). In contrast, it is well documented in birds that even small deviations in the amino acid sequence of the LBD drive species-specific differences in Ahr sensitivities (Karchner et al. 2006). Interestingly, studies on the mammalian Ahr indicate that the $\mathrm{C}$-terminal transactivation domain may play a larger role than the LBD in determining ligand sensitivity 
(Boutros et al. 2008; Wang et al. 2013). Thus, comparative and functional analyses conducted solely on the Ahr LBDs from fish must be interpreted with caution as differences in sensitivities and activation profiles amongst fish species may originate from features present elsewhere in the Ahr protein structures. Due to these limitations of the GAL4-LBD assay, it is important to emphasize that it does not necessarily reflect quantitative differences in ligand activation and sensitivities between high-Antarctic fish and Atlantic cod (Wang et al. 2013).

The results of the GAL4-LBD based reporter gene assay are also in line with previous findings in Antarctic Notothenioids from the gene expression or enzymatic level, which showed that $\mathrm{BaP}$ exposure causes an increase in $a h r 2$ and cypla expression and the enzymatic activity of Cyp1a, both underlining a responding Ahr pathway to PAHs (Regoli et al. 2005; Strobel et al. 2015). Yet, we observed differences between $C$. hamatus and $T$. loennbergii in the Ahr activation at the two highest chrysene concentrations tested in the reporter gene assays, in contrast to the responses we obtained for the ligands $\mathrm{BaP}$ and BNF. As such, a different in vitro induction of the Ahr and its downstream processes in response to certain PAHs is a first indicator of putative differences in the biotransformation metabolism between red- and white-blooded Notothenioids, and potentially the associated metabolis costs.

Despite these observed differences in the ligand activation by high doses of chrysene in C. hamatus and T. loennbergii, the overall response of the Ahr LBD to organic compounds was hardly distinct between the high-Antarctic fish and Atlantic cod in the reporter gene assay.

However, although we could only use the Ahr LBD in the assays, the measurement of Ahr related activation represents a great potential to provide a first estimate of the sensitivity of species to dioxin-like compounds. Especially considering the difficulties in obtaining various Antarctic fish species in a living state, this type of experiment offers an excellent opportunity for future ecotoxicology studies and to assess species differences in sensitivity to environmental contaminants in the Antarctic. The demand for such type of investigations will increase under the conditions of climate change, placing Antarctic fish under even higher numbers of stressors, resulting in a complex multiple stressor scenario. Here, the broad spectrum of Ahr functions has to be considered, as it is likely acting as a convergence point where various endogenous and external signals are integrated, including nutritional factors or molecules of the microbiome (Segner et al. 2021). Obtaining the full-length Ahr of various Antarctic fish species would be crucial here to develop a robust relationship between Ahr activation and stressor sensitivity.

Importantly, Antarctic fish possess generally low metabolic rates and only a slow xenobiotics metabolism, in comparison to temperate zone fish (Clarke 1991; Focardi et al.
1995; Möller et al. 2014a; Strobel et al. 2015). In the end, a functioning but slower xenobiotics metabolism and excretion would have consequences for e.g. the exposure time, bioconcentration and bioaccumulation of organic pollutants in the lipid-rich tissues of the Antarctic fish, and therefore the toxicity of individual POPs. As pointed out by Strobel et al. (2015), despite a functional Ahr pathway, the low biotransformation rates that appear to exist in Antarctic fishes implicate a high bioaccumulation of lipophilic contaminants, thus potentially putting Antarctic fish at risk even at low environmental exposure concentrations.

\section{Effects of of benzo[a]pyrene on hepatocyte energy metabolism}

Energy investment and allocation is a common functional response to environmental stressors at all levels of organization, and several studies underline shifts in an animal's energy budget as long-term consequence to environmental stress (Pörtner 2012; Sokolova et al. 2012). Many Notothenioids, however, already reside at the upper end of their thermal tolerance range, implying that they are energetically limited and their physiological performance is highly susceptible to additional environmental stress (Pörtner 2012; Pörtner and Lannig 2009). Thus, energetic limitations are a critical factor for their physiological capabilities to cope with environmental stressors such as anthropogenic pollutants, especially if they are altering the energy investment for functions such as growth or reproduction (Sandersfeld et al. 2016). In terms of energy production and storage, it is the liver which plays a central role and serves as hub of several metabolic pathways (Strobel et al. 2013). Moreover, it is a central organ in the Ahr-mediated metabolism of xenobiotics (Hinton et al. 2008). Indeed, a few studies already report an additional fraction of energy that is needed for detoxification processes (Ng and Gray 2011; Manciocco et al. 2014), and a few in vivo studies demonstrated altered hepatocyte metabolism in response to xenobiotics exposure in nonpolar fish (Bains and Kennedy 2005; Nault et al. 2012). Thus, there is a need to determine the metabolic capacities to cope with anthropogenic pollutants. Assessing hepatic metabolism in Antarctic fish is therefore of high value to evaluate their capacities to deal with emerging contaminants, and if resource competitions could arise with other energydemanding processes (French et al. 2009).

The hepatocyte respiration rates of $C$. hamatus and $T$. loennbergii that we measured under control conditions in this study were within the same order of magnitude as hepatocyte respiration rates of other Trematomus and Lepidonotothen species, the Antarctic eelpout $P$. brachycephalum (Langenbuch 2003; Mark et al. 2005), and to respiration rates of G. morhua (Stapp et al. 2015), rainbow trout or goldfish (Krumschnabel et al. 1997; Wieser and Krumschnabel 
2001). In fact, various studies on Antarctic Notothenioids suggest that there is no difference in their tissue oxidative capacities compared to cold-eurytherm fish, reflecting the perfect cold-adaptation in polar fishes (Johnston et al. 1998; Pörtner et al. 2000). Furthermore, the hepatocyte respiration was at the same level in T. loennbergii and C. hamatus, in line with previous reports on similar whole animal respiration rates in haemoglobin-less and red-blooded Antarctic fish (Ralph and Everson 1968).

Next, we observed no significant effect of $\mathrm{BaP}$ on the respiration rate of hepatocytes from $T$. loennbergii or $C$. hamatus. The existing data on the impact of Ahr-binding toxicants on cellular metabolism is indeed conflicting: whilst studies with rainbow trout hepatocytes reported an increase in oxygen consumption rate after exposure to pyrene (Bains and Kennedy 2005), other studies found that isolated primary hepatocyte cultures of rainbow trout did not change respiratory activity in response to PCB 77 and 126 (Nault et al. 2012). Theoretically, one would expect opposite findings, as PCB 77 and 126 are slowly metabolized, whereas $\mathrm{BaP}$ is rapidly metabolized so that the cost of biotransformation should be higher in the BaP-exposed trout hepatocytes. Probably, the energetic costs of biotransformation in the overall metabolic costs of hepatocytes are not high enough to cause significant changes in whole-cell respiration. This should be even more the case with Antarctic Notothenioid fish, which display particularly low rates of biotransformation (Strobel et al. 2015).

\section{Effects of benzo[a]pyrene on hepatic protein biosynthesis}

An induction of biotransformation by xenobiotics implicates the need for increased cellular protein synthesis in order to establish elevated levels of the relevant metabolic enzymes. Thus, we were interested to learn if the costs associated with $\mathrm{BaP}$ exposure are different if we consider specifically protein synthesis rather than the overall cellular metabolism.

Concerning the share of respiration dedicated to protein synthesis, hepatocytes of $T$. loennbergii and $C$. hamatus showed very similar values to those reported previously for Antarctic and non-polar fish species, including G. morhua (Krumschnabel et al. 1997; Langenbuch and Pörtner 2004; Mark et al. 2005; Lewis et al. 2015; Stapp et al. 2015). In BaP-exposed cells, the metabolic costs for protein synthesis increased significantly in C. hamatus to up to $40 \%$. In contrast, the respiration dedicated to protein synthesis in T. loennbergii tended to decrease to $13 \%$. Both values are either higher or lower than the costs for protein synthesis reported previously for Antarctic fish, in which they ranged from 18 to 37\% (Langenbuch and Pörtner 2004; Mark et al. 2005; Lewis et al. 2015). Even though not obvious when looking at overall hepatocyte respiration in BaP-exposed cells of $C$. hamatus, BaP thus had a clear effect on the allocation of cellular energy, indicating shifts towards protein synthesis. Such elevated protein synthesis, i.e. an increased translation efficiency could indeed support the detoxification of xenobiotics, including the Ahr pathway and downstream enzymatic biotransformation processes (Hinton et al. 2008). However, such metabolic shifts could also reduce the amount of energy available for other processes of the aerobic metabolism such as lipid or glycogen biosynthesis (Sidell et al. 1987; Windisch et al. 2011). Finally, this would lead to a mobilization of the liver energy stores such as glycogen or lipid, to compensate for the reduced amount of energy available for these pathways (Strobel et al. 2013).

In contrast to $C$. hamatus, $T$. loennbergii showed a different pattern with a tendency to a slightly reduced amount of protein metabolism, potentially to foster other processes. Indeed, protein synthesis is proposed to be the most sensitive process to changes in cellular energy supply (Wieser and Krumschnabel 2001). Accordingly, an increased demand by other energy-demanding processes could negatively affect the costs dedicated to protein synthesis in BaP-exposed hepatocytes of $T$. loennbergii. To this end, the shifts in metabolic pathways that we observed for $C$. hamatus and tendentially for $T$. loennbergii would affect energy stores of both the white- and red-blooded Notothenioids, and consequently the whole animal performance in the long run.

\section{Conclusion}

With the results of the present study, we provide initial evidence that $\mathrm{BaP}$ can transactivate Ahr2s from Antarctic Notothenioids, suggesting that PAHs activate the Ahr signalling pathway in these fish. This finding is of relevance as it indicates that functional losses of elements of the defensome such as the heat shock response and Pxr, as observed in a number of fish species from extreme environments (Eide et al. 2018), do not extend to all members of the cellular defensome.

Further evidence for the functional activation of the Ahr pathway in Antarctic Notothenioids comes from the observation that it is associated with increased energy allocation to hepatocellular protein synthesis. Remarkably, the latter response display differences between the red- and white-blooded Notothenioids. The question remains what consequences the BaP-induced shift in the cellular energy allocation might have for the overall energy metabolism of Notothenioids and thus the overall performance of the animals in the long term.

Supplementary Information The online version contains supplementary material available at https://doi.org/10.1007/s00300-021-02992-4. 
Acknowledgements We are grateful to F. C. Mark and N. Koschnick (Alfred Wegener Institute, Helmholtz Centre for Polar and Marin Research) for their support during the expedition with RV Polarstern. We would like to acknowledge H. Schiffer (University of Basel) for her valuable assistance in the laboratory. Thanks also to M. Hahn (Woods Hole Oceanographic Institution) for his advice in preparing Ahr primers. We are also grateful to Alexander Klevedal Madsen for preparing the plasmid expressing the Atlantic cod LBD fused to the GAL4 DBD. This project was funded by the Swiss National Science Foundation (grant number: SNSF 31003A_149964/1 and IZK0Z3_173426/1) and the Freiwillige Akademische Gesellschaft Basel. Furthermore, this work was supported by the projects iCod 2.0 (grant number: 244564) and dCod 1.0 (grant number: 248840) funded by the Research Council of Norway.

Funding Open Access funding enabled and organized by Projekt DEAL.

Open Access This article is licensed under a Creative Commons Attribution 4.0 International License, which permits use, sharing, adaptation, distribution and reproduction in any medium or format, as long as you give appropriate credit to the original author(s) and the source, provide a link to the Creative Commons licence, and indicate if changes were made. The images or other third party material in this article are included in the article's Creative Commons licence, unless indicated otherwise in a credit line to the material. If material is not included in the article's Creative Commons licence and your intended use is not permitted by statutory regulation or exceeds the permitted use, you will need to obtain permission directly from the copyright holder. To view a copy of this licence, visit http://creativecommons.org/licenses/by/4.0/.

\section{References}

Abnet CC, Tanguay RL, Hahn ME, Heideman W, Peterson RE (1999) Two forms of aryl hydrocarbon receptor type 2 in rainbow trout (Oncorhynchus mykiss) evidence for differential expression and enhancer specificity. J Biol Chem 274:15159-15166

Aranguren-Abadía L, Lille-Langoy R, Madsen AK, Karchner SI, Franks DG, Yadetie F, Hahne ME, Goksoyr A, Karlsen OA (2020) Molecular and functional properties of the atlantic cod (Gadus morhua) aryl hydrocarbon receptors Ahr1a and Ahr2a. Environ Sci Technol 54:1033-1044. https://doi.org/10.1021/acs.est.9b053 12

Bains OS, Kennedy CJ (2005) Alterations in respiration rate of isolated rainbow trout hepatocytes exposed to the P-glycoprotein substrate rhodamine 123. Toxicology 214:87-98. https://doi.org/10.1016/j. tox.2005.06.002

Barnes DK, Peck LS (2008) Vulnerability of Antarctic shelf biodiversity to predicted regional warming. Clim Res 37:149-163

Beers JM, Sidell BD (2011) Thermal tolerance of Antarctic notothenioid fishes correlates with level of circulating hemoglobin. Physiol Biochem Zool 84:353-362. https://doi.org/10.1086/660191

Bennett JR, Shaw JD, Terauds A, Smol JP, Aerts R, Bergstrom DM, Blais JM, Cheung WWL, Chown SL, Lea M-A, Nielsen UN, Pauly D, Reimer KJ, Riddle MJ, Snape I, Stark JS, Tulloch VJ, Possingham HP (2015) Polar lessons learned: long-term management based on shared threats in Arctic and Antarctic environments. Front Ecol Environ 13:316-324. https://doi.org/10.1890/ 140315

Billiard SM, Hahn ME, Franks DG, Peterson RE, Bols NC, Hodson PV (2002) Binding of polycyclic aromatic hydrocarbons (PAHs) to teleost aryl hydrocarbon receptors (AHRs). Comp Biochem Physiol B Biochem Mol Biol 133:55-68
Blanco M, Pérez-Albaladejo E, Piña B, Kušpilić G, Milun V, LilleLangøy R, Karlsen OA, Goks øyr A, Porte C (2018) Assessing the environmental quality of sediments from Split coastal area (Croatia) with a battery of cell-based bioassays. Sci Total Environ 624:1640-1648. https://doi.org/10.1016/j.scitotenv.2017.10.055

Blumberg B, Sabbagh W Jr, Juguilon H, Bolado J Jr, van Meter CM, Ong ES, Evans RM (1998) SXR, a novel steroid and xenobioticsensing nuclear receptor. Genes Dev 12:3195-3205

Boutros PC, Yan R, Moffat ID, Pohjanvirta R, Okey AB (2008) Transcriptomic responses to 2,3,7,8-tetrachlorodibenzo-p-dioxin (TCDD) in liver: comparison of rat and mouse. BMC Genom 9:419. https://doi.org/10.1186/1471-2164-9-419

Chao H-R, Wang Y-F, Wang Y-N, Lin D-Y, Gou Y-Y, Chen C-Y, Chen K-C, Wu W-K, Chiang B-A, Huang Y-T, Hsieh L-T, Yeh K-JC, Tsou T-C (2012) An improved AhR reporter gene assay for analyzing dioxins in soil, sediment and fish. Bull Environ Contam Toxicol 89:739-743

Clarke A (1991) What is cold adaptation and how should we measure it? Amer Zool 31:81-92

Corsolini S, Kannan K, Imagawa T, Focardi S, Giesy JP (2002) Polychloronaphthalenes and other dioxin-like compounds in Arctic and Antarctic marine food webs. Environ Sci Technol 36:3490-3496

Corsolini S, Ademollo N, Romeo T, Olmastroni S, Focardi S (2003) Persistent organic pollutants in some species of a Ross Sea pelagic trophic web. Ant Sci 15:95-104

Denison MS, Nagy SR (2003) Activation of the aryl hydrocarbon receptor by structurally diverse exogenous and endogenous chemicals. Annu Rev Pharmacol Toxicol 43:309-334. https://doi.org/ 10.1146/annurev.pharmtox.43.100901.135828

Doering JA, Giesy JP, Wiseman S, Hecker M (2013) Predicting the sensitivity of fishes to dioxin-like compounds: possible role of the aryl hydrocarbon receptor (AhR) ligand binding domain. Environ Sci Pollut Res 20:1219-1224. https://doi.org/10.1007/ s11356-012-1203-7

Doering JA, Farmahin R, Wiseman S, Beitel SC, Kennedy SW, Giesy JP, Hecker M (2015) Differences in activation of aryl hydrocarbon receptors of white sturgeon relative to lake sturgeon are predicted by identities of key amino acids in the ligand binding domain. Enviro Sci Technol 49:4681-4689

Eastman JT (2005) The nature of the diversity of Antarctic fishes. Polar Biol 28:93

Eide M, Rydbeck H, Tørresen OK, Lille-Langøy R, Puntervoll P, Goldstone JV, Jakobsen KS, Stegeman J, Goksøyr A, Karlsen OA (2018) Independent losses of a xenobiotic receptor across teleost evolution. Sci Rep 8:10404. https://doi.org/10.1038/ s41598-018-28498-4

Eide M, Zhang X, Karlsen OA, Goldstone JV, Stegeman J, Jonassen I, Goksøyr A (2021) The chemical defensome of five model teleost fish. Sci Rep 11:1-13

Evans DH, Piermarini PM, Choe KP (2005) The multifunctional fish gill: dominant site of gas exchange, osmoregulation, acidbase regulation and excretion of nitrogenous waste. Physiol Rev 85:97-177

Fay KA, Fitzsimmons PN, Hoffman AD, Nichols JW (2014) Optimizing the use of rainbow trout hepatocytes for bioaccumulation assessments with fish. Xenobiotica 44:345-351. https://doi.org/ 10.3109/00498254.2013.845704

Focardi S, Fossi M, Lari L, Casini S, Leonzio C, Meidel S, Nigro M (1995) Induction of MFO activity in the antarctic fish Pagothenia bernacchii: preliminary results. Mar Environ Res 39:97-100

Forman B, Umesono K, Chen J, Evans R (1995) Unique response pathways are established by allosteric interactions among nuclear hormone receptors. Cell 81:541-550. https://doi.org/10.1016/00928674(95)90075-6

Fraccalvieri D, Soshilov AA, Karchner SI, Franks DG, Pandini A, Bonati L, Hahn ME, Denison MS (2013) Comparative analysis 
of homology models of the Ah receptor ligand binding domain: verification of structure-function predictions by site-directed mutagenesis of a nonfunctional receptor. Biochemistry 52:714725. https://doi.org/10.1021/bi301457f

French SS, Moore MC, Demas GE (2009) Ecological immunology: the organism in context. Integr Comp Biol 49:246-253

Garofalo F, Pellegrino D, Amelio D, Tota B (2009) The Antarctic hemoglobinless icefish, fifty five years later: a unique cardiocirculatory interplay of disaptation and phenotypic plasticity. Comp Biochem Physiol A Mol Integr Physiol 154:10-28. https://doi.org/ 10.1016/j.cbpa.2009.04.621

Gon O, Heemstra P (1990) Fishes of the Southern Ocean. J.L.B. Smith Institute for Ichthyology, Grahamstown, South Africa

Goutte A, Chevreuil M, Alliot F, Chastel O, Cherel Y, Eléaume M, Massé G (2013) Persistent organic pollutants in benthic and pelagic organisms off Adélie Land, Antarctica. Mar Pollut Bull 77:82-89

Grun F, Venkatesan RN, Tabb MM, Zhou C, Cao J, Hemmati D, Blumberg B (2002) Benzoate X receptors alpha and beta are pharmacologically distinct and do not function as xenobiotic receptors. J Biol Chem 277:43691-43697. https://doi.org/10. 1074/jbc.M206553200

Hahn ME, Karchner SI, Evans BR, Franks DG, Merson RR, Lapseritis JM (2006) Unexpected diversity of aryl hydrocarbon receptors in non-mammalian vertebrates: insights from comparative genomics. J Exp Zool A Comp Exp Biol 305:693-706

Hansson MC, Hahn ME (2008) Functional properties of the four Atlantic salmon (Salmo salar) aryl hydrocarbon receptor type 2 (AHR2) isoforms. Aquat Toxicol 86:121-130

Hinton DE, Segner H, Au DW, Kullman SW, Hardman RC (2008) Liver Toxicity. In: Di Giulio RT, Hinton DE (eds) Toxicology of fishes. CRC Press, Boca Raton, pp 327-400

IPCC (2014) Fifth Assessment Report of the Intergovernmental Panel on Climate Change.

Johnston IA, Calvo J, Guderley H, Fernandez D, Palmer L (1998) Latitudinal variation in the abundance and oxidative capacities of muscle mitochondria in perciform fishes. J Exp Biol 201:1-12

Jönsson ME, Gao K, Olsson JA, Goldstone JV, Brandt I (2010) Induction patterns of new CYP1 genes in environmentally exposed rainbow trout. Aquat Toxicol 98:311-321. https://doi.org/10.1016/j. aquatox.2010.03.003

Karchner SI, Franks DG, Hahn ME (2005) AHR1B, a new functional aryl hydrocarbon receptor in zebrafish: tandem arrangement of ahr $1 \mathrm{~b}$ and ahr2 genes. Biochem 392:153-161

Karchner SI, Franks DG, Kennedy SW, Hahn ME (2006) The molecular basis for differential dioxin sensitivity in birds: role of the aryl hydrocarbon receptor. Proc Natl Acad Sci 103:6252-6257

King-Heiden TC, Mehta V, Xiong KM, Lanham KA, Antkiewicz DS, Ganser A, Heideman W, Peterson RE (2012) Reproductive and developmental toxicity of dioxin in fish. Mol Cell Endocrinol 354:121-138

Krumschnabel G, Biasi C, Schwarzbaum PJ, Wieser W (1997) Acute and chronic effects of temperature, and of nutritional state, on ion homeostasis and energy metabolism in teleost hepatocytes. J Comp Physiol B 167:280-286

Langenbuch M (2003) Energy budget of hepatocytes from Antarctic fish (Pachycara brachycephalum and Lepidonotothen kempi) as a function of ambient $\mathrm{CO}_{2}: \mathrm{pH}$-dependent limitations of cellular protein biosynthesis? J Exp Biol 206:3895-3903. https://doi.org/ 10.1242/jeb.00620

Langenbuch M, Pörtner HO (2004) High sensitivity to chronically elevated $\mathrm{CO}_{2}$ levels in a eurybathic marine sipunculid. Aquat Toxicol 70:55-61

Lewis JM, Grove TJ, O'Brien KM (2015) Energetic costs of protein synthesis do not differ between red- and white-blooded Antarctic notothenioid fishes. Comp Biochem Physiol A Mol Integr Physiol 187:177-183. https://doi.org/10.1016/j.cbpa.2015.05.026

Lille-Langoy R, Goldstone JV, Rusten M, Milnes MR, Male R, Stegeman JJ, Blumberg B, Goksøyr A (2015) Environmental contaminants activate human and polar bear (Ursus maritimus) pregnane $\mathrm{X}$ receptors (PXR, NR1I2) differently. Toxicol Appl Pharmacol 284:54-64. https://doi.org/10.1016/j.taap.2015.02.001

Madsen A (2016) Cloning, charachterisation and ligand activation of Atlantic cod aryl hydrocarbon receptor 2 (Ahr2). Master's, University of Bergen

Manciocco A, Calamandrei G, Alleva E (2014) Global warming and environmental contaminants in aquatic organisms: The need of the etho-toxicology approach. Chemosphere 100:1-7. https://doi.org/ 10.1016/j.chemosphere.2013.12.072

Mark FC, Hirse T, Pörtner H-O (2005) Thermal sensitivity of cellular energy budgets in some Antarctic fish hepatocytes. Polar Biol 28:805-814

Mark FC, Lucassen M, Strobel A, Barrera-Oro E, Koschnick N, Zane L, Patarnello T, Pörtner H-O, Papetti C (2012) Mitochondrial function in Antarctic nototheniids with ND6 translocation. PLoS ONE 7:e31860. https://doi.org/10.1371/journal.pone.0031860

Matschiner M, Hanel R, Salzburger W (2011) On the origin and trigger of the notothenioid adaptive radiation. PLoS ONE 6:e18911

Miller HC, Mills GN, Bembo DG, Macdonald JA, Evans CW (1998) Induction of cytochrome P4501A (CYP1A) in Trematomus bernacchii as an indicator of environmental pollution in Antarctica: assessment by quantitative RT-PCR. Aquat Toxicol 44:183-193. https://doi.org/10.1016/S0166-445X(98)00075-7

Möller A-M, Korytáŕ T, Köllner B, Schmidt-Posthaus H, Segner H (2014a) The teleostean liver as an immunological organ: Intrahepatic immune cells (IHICs) in healthy and benzo [a] pyrene challenged rainbow trout (Oncorhynchus mykiss). Dev Comp Immunol 46:518-529

Möller AM, Hermsen C, Floehr T, Lamoree MH, Segner H (2014b) Tissue-specific metabolism of benzo [a] pyrene in rainbow trout (Oncorhynchus mykiss): a comparison between the liver and immune organs. Drug Metab Dispos 42:111-118

Mommsen TP, Moon TW, Walsh PJ (1994) Hepatocytes: isolation, maintenance and utilization. In: Hochachka PW, Mommsen TP (eds) Biochemistry and molecular biology of fishes, analytical techniques, vol 3. Elsevier Science, Amsterdam, pp 355-372

Nault R, Al-Hameedi S, Moon TW (2012) Effects of polychlorinated biphenyls on whole animal energy mobilization and hepatic cellular respiration in rainbow trout, Oncorhynchus mykiss. Chemosphere 87:1057-1062. https://doi.org/10.1016/j.chemosphere. 2012.02.012

Ng CA, Gray KA (2011) Forecasting the effects of global change scenarios on bioaccumulation patterns in great lakes species. Glob Change Biol 17:720-733

Papetti C, Lio P, Ruber L, Patarnello T, Zardoya R (2007) Antarctic fish mitochondrial genomes lack ND6 gene. J Mol Evol 65:519-528

Pörtner H-O (2006) Climate-dependent evolution of Antarctic ectotherms: an integrative analysis. Deep Sea Res Part II Top Stud Oceanogr 53:1071-1104. https://doi.org/10.1016/j.dsr2.2006.02. 015

Pörtner H-O (2012) Integrating climate-related stressor effects on marine organisms: unifying principles linking molecule to ecosystem-level changes. Mar Ecol Prog Ser 470:273-290

Pörtner H-O, Lannig G (2009) Oxygen and capacity limited thermal tolerance. In: Richards JG, Farrell AP, Brauner C (eds) Fish physiology, vol 27. Academic Press, Burlington, pp 143-191

Pörtner H-O, Van Dijk P, Hardewig I, Sommer A (2000) Levels of metabolic cold adaptation: trade-offs in eurythermal and stenothermal ectotherms. In: Davison W, Howard Williams C (eds) Antarctic ecosystems: models for wider ecological understanding. New Zealand Natural Sciences, Christchurch, pp 109-122 
Ralph R, Everson I (1968) The respiratory metabolism of some Antarctic fish. Comp Biochem Physiol 27:299-307. https://doi.org/ 10.1016/0010-406x(68)90772-x

Regoli F, Nigro M, Benedetti M, Gorbi S, Pretti C, Gervasi PG, Fattorini D (2005) Interactions between metabolism of trace metals and xenobiotic agonists of the aryl hydrocarbon receptor in the antarctic fish Trematomus bernacchii: environmental perspectives. Environ Toxicol Chem 24:1475-1482

Roy NK, Walker N, Chambers RC, Wirgin I (2011) Characterization and expression of cytochrome P4501A in Atlantic sturgeon and shortnose sturgeon experimentally exposed to coplanar PCB 126 and TCDD. Aquat Toxicol 104:23-31

Sandersfeld T, Mark FC, Knust R (2016) Temperature-dependent metabolism in Antarctic fish: do habitat temperature conditions affect thermal tolerance ranges? Polar Biol 40(1):141-149

Segner H (1998) Isolation and primary culture of teleost hepatocytes. Comp Biochem Physiol : Mol Integr Physiol 120:71-81

Segner H, Bailey C, Tafalla C, Bo J (2021) Immuntoxicity of xenobiotics in fish: a role for the aryl hydrocarbon receptor (AhR)? Int $\mathbf{J}$ Mol Sci 22:9460

Sidell BD, O'Brien KM (2006) When bad things happen to good fish: the loss of hemoglobin and myoglobin expression in Antarctic icefishes. J Exp Biol 209:1791-1802

Sidell BD, Driedzic WR, Stowe DB, Johnston IA (1987) Biochemical correlations of power development and metabolic fuel preferenda in fish hearts. Physiol Zool 60:221-232

Sleiderink HM et al (1995) Influence of temperature and polyaromatic contaminants on CYP1A levels in North Sea dab (Limanda limanda). Aquat Toxicol 32:189-209

Sokolova IM, Frederich M, Bagwe R, Lannig G, Sukhotin AA (2012) Energy homeostasis as an integrative tool for assessing limits of environmental stress tolerance in aquatic invertebrates. Mar Environ Res 79:1-15

Stapp LS, Kreiss CM, Pörtner HO, Lannig G (2015) Differential impacts of elevated $\mathrm{CO}_{2}$ and acidosis on the energy budget of gill and liver cells from Atlantic cod, Gadus morhua. Comp Biochem Physiol A Mol Integr Physiol 187:160-167. https://doi.org/10. 1016/j.cbpa.2015.05.009

Strobel A, Leo E, Pörtner H-O, Mark FC (2013) Elevated temperature and $\mathrm{PCO}_{2}$ shift metabolic pathways in differentially oxidative tissues of Notothenia rossii. Comp Biochem Physiol B Biochem Mol Biol 166:48-57
Strobel A, Burkhardt-Holm P, Schmid P, Segner H (2015) Benzo (a) pyrene metabolism and EROD and GST biotransformation activity in the liver of red-and white-blooded antarctic fish. Environ Sci Technol 49:8022-8032

Strobel A, Schmid P, Segner H, Burkhardt-Holm P, Zennegg M (2016) Persistent organic pollutants in tissues of the white-blooded Antarctic fish Champsocephalus gunnari and Chaenocephalus aceratus. Chemosphere 161:555-562

Strobel A, Schmid P, Burkhardt-Holm P, Segner H, Zennegg M (2018) Persistent organic pollutants in red- and white-blooded high-antarctic notothenioid fish from the remote Weddell Sea. Chemosphere 193:213-222. https://doi.org/10.1016/j.chemosphere.2017. 11.020

Wang Y, Wang Q, Wu B, Li Y, Lu G (2013) Correlation between TCDD acute toxicity and aryl hydrocarbon receptor structure for different mammals. Ecotoxicol Environ Saf 89:84-88. https://doi. org/10.1016/j.ecoenv.2012.11.016

Wania F, Mackay D (1996) Tracking the distribution of persistent organic pollutants. Environ Sci Technol 30:390A-396A

Weyermann J, Lochmann D, Zimmer A (2005) A practical note on the use of cytotoxicity assays. Int J Pharm 288:369-376. https://doi. org/10.1016/j.ijpharm.2004.09.018

Wieser W, Krumschnabel G (2001) Hierarchies of ATP-consuming processes: direct compared to indirect measurements, and comparative aspects. Biochem J 355:389-395

Windisch HS, Kathöver R, Pörtner H-O, Frickenhaus S, Lucassen M (2011) Thermal acclimation in Antarctic fish: Transcriptomic profiling of metabolic pathways. Am J Physiol 301:R1453-R1466. https://doi.org/10.1152/ajpregu.00158.2011

Yamauchi M, Kim E-Y, Iwata H, Shima Y, Tanabe S (2006) Toxic effects of 2, 3, 7, 8-tetrachlorodibenzo-p-dioxin (TCDD) in developing red seabream (Pagrus major) embryo: an association of morphological deformities with AHR1, AHR2 and CYP1A expressions. Aquat Toxicol 80:166-179

Publisher's Note Springer Nature remains neutral with regard to jurisdictional claims in published maps and institutional affiliations. 